\title{
Teaching Writing to EFL Student Teachers: Teachers' Intervention and No Teachers' Intervention through Peer Feedback Writing Techniques
}

\author{
Anissa Astrid ${ }^{1}$, Lenny Marzulina ${ }^{1}$, Dian Erlina ${ }^{1}$, Kasinyo Harto ${ }^{1}$, Akhmad Habibi ${ }^{2}$, \\ Amirul Mukminin ${ }^{2, *}$ \\ ${ }^{1}$ Faculty of Tarbiyah and Teaching Sciences, State Islamic University of Raden Fatah, Indonesia \\ ${ }^{2}$ Doctoral Program in Education, the Graduate School, Universitas Jambi, Indonesia
}

Copyright $\bigcirc 2019$ by authors, all rights reserved. Authors agree that this article remains permanently open access under the terms of the Creative Commons Attribution License 4.0 International License

\begin{abstract}
The purpose of this study was to find out the impacts of teachers' intervention and no teachers' intervention peer feedback writing techniques (PFWT) on English as a foreign language (EFL) student teachers' essay writing ability and their perceptions of learning activities viewed on their level of writing anxiety. The study was conducted in one English education study program at an Indonesian state Islamic university. Writing tests were used to find out whether or not the treatments had the impact on student teachers' essay writing achievement while a questionnaire was used to gain student teachers' perceptions of writing activities. Two groups of student teachers taking a writing course were selected as participants. Data were analyzed by using Two Way ANOVA, Descriptive statistics analysis, and non-parametric test. The findings indicated that no teachers' intervention PFWT had a significant impact on student teachers' writing ability and the impact was influenced by the different levels of students' writing anxiety. Additionally, teachers' intervention PFWT had a significant effect on both students' having low and high writing anxiety. Finally, students having low writing anxiety perceived teachers' intervention PFWT more positively compared to those having high writing anxiety.
\end{abstract}

Keywords Collaborative Peer Feedback, Students' Writing Anxiety, Teachers' Intervention

\section{Introduction}

EFL Students usually face difficulties in writing even to produce a single paragraph. Writing in a foreign language (FL) is even more difficult as it demands a certain amount of knowledge on the language background. How the language works in a composition, what are the necessary connectors to link the ideas, and what are the appropriate words to deliver the author's messages to the readers (Failasofah \& Dayij Alkhrisheh, 2018; Mukminin, Ali, \& Ashari, 2015; Makmur, Mukminin, Ismiyati, \& Verawaty, 2016; Situmorang, 2018), as writing is a difficult skill that makes writing frequently neglected by students. According to Dixon (2005, p.2), "writing skills is frequently ignored and regarded as the least priority in English classes." For example, Alwasilah (2006) in his study found that $48 \%$ of 179 EFL students saw writing as a neglected subject to take due to the fact that writing class was time-consuming.

Several approaches have been proposed to facilitate students to become fluent in writing. The first writing approach was influenced by the structural linguistics and behaviorists in the 1960s. According to the structural linguistics theories, writing is treated as a product and emphasized grammatical features of texts. Hyland (2003) argues that writing teachers who believe in the product approach in teaching writing naturally emphasize linguistic knowledge, vocabulary choices, and syntactic patterns that are essential for the formation of written texts as a product. After contradictions to the product approach in teaching writing, the process approach to writing was introduced in 1980 s, which was most widely accepted by L2 writing teachers. It was the planning-writing-reviewing framework established by Flower and Hayes (1981). In the process approach, the way of teaching has shifted from focusing on students' final product to the process of writing comprising of four basic writing stages: planning, drafting (writing), revising (redrafting), and editing.

The process approach reflects the fact that writing involves a relationship between the writer and his or her audience that produces an awareness of authentic social situations and an affinity to collaborate with others (Boas, 
2011). Therefore, the process approach fits the socio-constructivists' view of education that suggests successful learning is enhanced when it is based on the needs, worldview, and sociocultural backgrounds of the learners. Giving and sharing feedback is part of the process of editing and redrafting in process writing approach. Traditionally, teacher is the only one who provides feedback for students' writing in both content and corrective feedback. Feedback from teachers in the form of written feedback can be defined as a process through which a teacher communicates with students about how they responded to a task (Ferris, 1995; Hyland and Hyland, 2003). This kind of feedback technique is useful for teachers in clarifying the information, giving clues and suggestions, and asking the students to do revisions.

However, there are many views against the implementation of teacher feedback writing technique. One of the important issues related to teacher feedback writing technique is the issue of text appropriation. Knoblauch and Brannon (1984) argue that writing could be stolen from a writer by the teachers' comments. They argue that by following a directive feedback closely, students do not develop either their cognitive or their writing skills through their writing, but merely rewrite texts to reflect their teachers' preoccupations. Moreover, Zamel (1985) and Cohen (1987) maintain that teachers' comments on ESL compositions are at times inconsistent. Cohen (1987) suggests that teachers' comments on students work are often confusing, vague and not focused enough, in the areas where learners are in need of feedback. Meanwhile, Pinako and Radzik (1980) informed that students, sometimes, do not trust the feedback they receive from the teacher because they assumed that the teacher did not understand the points they were trying to make since she/he is from a different generation. Many students think that their friends would better understand their thoughts.

As a result of ineffectiveness and student non-appropriation of teacher feedback, the use of peer feedback is widespread in the teaching writing (Ferris, 2003). Peer feedback is seen as a way of giving more control to students since it allows them to make active decisions on whether or not to use their peers' comments as opposed to passive reliance on teachers' feedback (Leki, 1990; Mendonca \& Johnson, 1994; Reid, 1994). Classically, peer feedback is a kind of activity where the students share the feedbacks with each other in groups of four or five people. Each student gives one copy of his/ her paper to every member of the group. Then, usually as homework, each group will be asked to read their peers' writing and prepare feedbacks/ comments. In the next meeting, students in each group will be asked to discuss by giving oral comments on each paper they read, as well as ask and answer clarifying questions. Then, each student uses this feedback from the other group members to revise their writing (Byrd, 2003; Liu \& Hansen, 2002; Mittan, 1989; Nelson \& Murphy, 1993; Paulus, 1999).
Peer feedback has been advocated in several studies for a number of benefits. For example, Hyland (2000) mentioned that peer feedback encouraged students to participate in the classroom activity and made them less passively teacher-dependent. Meanwhile, Yarrow and Topping (2001) claimed that peer feedback played a pivotal role in increased engagement and time spent on-task, immediacy and individualization of help, goal specification, explaining, and prevention of information processing overload, promoting, modelling and reinforcement. Yang, Badger, and $\mathrm{Yu}$ (2006) add that peer feedback is beneficial in developing critical thinking, learner autonomy and social interaction among students. More importantly, the practice of peer feedback allows students to receive more individual comments as well as to give reviewers the opportunity to practice and develop different language skills.

Despite of the benefits, the failure of peer feedback technique was illustrated by several studies. Ashwell (2000) found that students only gave comments more on grammar than the content of their friends' writing. It was because students did not have enough knowledge on coherence and cohesion. Besides, Holec (1981) asserted that some teachers of English did not regard the activities of reading and exchanging comments as the important activities in learning processes. It is because of students' lack of writing skills and lack of time. Then, Nelson and Murphy (1993) found that Chinese-speaking students were less likely to accept the right of other non-native speakers of English to judge their writing. Finally, Mendoca and Johnson (1994) revealed that students were very selective about using peer comments in their revisions.

Furthermore, Hyland (2002) emphasizes that because L2 students generally lack the language competence of native speakers who can often react intuitively to their classmates' papers, peer response practices are most effective if they are modelled, taught, and controlled. Rollinson (2005) adds that peer response training can lead to significantly more meaning changes and higher marks on L2 writers' second draft regardless of proficiency levels, and the peer response literature advocate teacher input prior to the first feedback session. The objectives of pre-training are numerous and overlapping, but broadly speaking concern three areas: awareness raising (the principles and objectives of peer response); productive group interaction (collaboration, supportiveness, tact, etiquette); and productive response and revision (basic procedures, effective commenting, reader-writer dialogue, and effective revision).

Psychologically, it is claimed that there is personality factor that might unlikely affect students' writing achievement, like what Byrne (1993) mentions that Writing also has come into the psychological value for students as a form to support to learn. Byrne (1993) explains that to see the essence of writing in psychological problems, the reason why writing is difficult is that writing is a solitary activity in which there is no interaction 
processes. In the eye of foreign language learning, psychologically, one kind of affective factors in language learning comes across with the term "anxiety". Writing anxiety or writing apprehension is defined in a variety of ways. It is used generally to mean the negative and anxious feelings that disrupt part of the writing process. It also relates to the tendency of people to approach or to avoid writing (Cheng, Horwitz, \& Schalert, 1999; Daly \& Miller, 1975).

While a growing body of previous studies have addressed the causes of why writing is difficult to do psychologically, linguistically, and cognitively. Not much research, however, specifically explores how teachers' intervention and no teachers' intervention peer feedback writing techniques (PFWT) impact on English as a foreign language (EFL) student teachers' essay writing ability in a non-English speaking country like Indonesia viewed on the students' level of writing anxiety. Thus, we were interested in conducting a research which aimed at finding out the impacts of teachers' intervention and no teachers' intervention peer feedback writing techniques (PFWT) on English as a foreign language (EFL) student teachers' essay writing ability and their perceptions toward learning activities viewed on students' level of writing anxiety.

\section{Method}

\subsection{Design}

In this research, we employed the experimental method with a factorial design $2 \times 2$ and survey approaches (Fraenkel \& Wallen, 2012). Writing tests were used to find out whether or not the treatments had the impact on student teachers' essay writing achievement while a questionnaire was used to gain student teachers' perceptions of learning activities. Two groups of student teachers taking a writing course were selected as participants in one English education study program at an Indonesian state Islamic university. Participants in the first group consisting of 25 students were taught by using non-teachers' intervention peer feedback and in the second group consisting of 21 students were taught by using teachers' intervention peer feedback writing technique. A diagram of a factorial design is as follows:

Table 1. A diagram of a factorial design

\begin{tabular}{|c|c|c|}
\hline \multirow{2}{*}{$\begin{array}{c}\text { writing } \\
\text { anxiety }\end{array}$} & $\begin{array}{c}|c| \\
\text { peer feedback with no } \\
\text { teachers' intervention } \\
\text { (A1) }\end{array}$ & $\begin{array}{c}\text { peer feedback with } \\
\text { teachers' intervention } \\
\text { (A2) }\end{array}$ \\
\hline Low (B1) & A1B1 & A2B1 \\
\hline High (B2) & A1B2 & A2B2 \\
\hline
\end{tabular}

\subsection{Procedures}

We did the following procedures. Firstly, students were asked to do the pretest. The students were asked to choose one out of the four topics to be elaborated into an essay. In order to score the writing, we chose two independent lecturers from other universities as the raters of students' writing. The raters scored the students' writing based on the existing writing band (writing rubric) established from the experts. We asked the two raters to employ a scoring rubric developed by Hyland (2003). Then, they were asked to fulfill each item in SLWAI (Second Language Writing Anxiety Inventory) questionnaire prior to the treatments. The questionnaire used to measure students' writing anxiety was adopted from the one developed by Cheng (2004) named Second Language Writing Anxiety Inventory (SLWAI).

Additionally, the process of teaching and learning writing in each group was conducted in 15 meetings. In the first group, the students were taught by using no teacher intervention peer feedback technique; meanwhile, in the second group, the students were taught by using teachers' intervention peer feedback writing technique. After participating in 15 meetings, the students in each group were given the posttest. Finally, they were asked to fulfill the questionnaire. The items of the questionnaire were adapted from Tsui and Ng (2000), Miao et al. (2005), and Liu and Chai (2009) to assess students' perceptions and attitudes toward the learning processes of the implementation of peer feedback writing techniques. The items of the questionnaire were formulated in order to explore students' perceptions of the implementation of writing feedback techniques in each treatment group. The items were formulated by using Likert Scale; Strongly Disagree $=1$, Disagree $=2$, Undecided $=3$, Agree $=4$ and Strongly Agree $=5$. Before the questionnaire being administered to the students, there had been such a pilot study to ensure the reliability of that questionnaire.

The range was calculated for the scale where the range was $5-1=4$. By dividing the range by the number of categories (6), the result would be $4 / 5=0.8$, which represented the length of each category of the five scales. Next, the length of the category was added to the lowest grade of the scale, which is the number one (1). So the first category was represented by the following equation $(1+0.8=1.8)$ (Dornyei, 2003). This process was applied to the remaining categories as listed in Table 2.

Table 2. The Range of scale used for analysing the results of the closed ended questionnaire items

\begin{tabular}{|c|c|}
\hline Scale & The range \\
\hline Strongly Disagree & $>1$ to 1,8 \\
\hline Disagree & $>1,8$ to 2,6 \\
\hline Undecided & $>2,6$ to 3,4 \\
\hline Agree & $>3,4$ to 4,2 \\
\hline Strongly Agree & $>4,2$ to 5 \\
\hline
\end{tabular}

The data collected were analysed statistically by employing SPSS. The data gained from students' writing 
tests were analysed to ensure the normality of the data. Then, they were analysed by using homogeneity test to ensure the data were homogeneous. Finally, Two Way ANOVA was conducted to find out the impact of the implementation of teachers' intervention peer feedback writing on students' writing ability viewed from their writing anxiety. Meanwhile, the data gained from perception questionnaire were analysed by using descriptive statistics and non-parametric test.

\section{Findings}

\subsection{The Effect of the Implementation of Teacher's Intervention Peer Feedback Writing}

After the data were analysed in order to see their normality and homogeneity, the results were listed in Table 3. The data description of students' essay writing scores of their pretest and posttest was based on feedback writing techniques and the students' language writing anxiety as follows:
Table 3. The summary of descriptive test of students' posttest scores

\begin{tabular}{|c|c|c|c|c|}
\hline No & Groups & $\mathrm{N}$ & Sig. & $\alpha$ \\
\hline 1 & $\mathrm{~A}_{1}$ & 25 & 0,200 & 0,05 \\
\hline 2 & $\mathrm{~A}_{2}$ & 22 & 0,200 & 0,05 \\
\hline 3 & $\mathrm{~B}_{1}$ & 20 & 0,200 & 0,05 \\
\hline 4 & $\mathrm{~B}_{2}$ & 26 & 0,076 & 0,05 \\
\hline 5 & $\mathrm{~A}_{1} \mathrm{~B}_{1}$ & 11 & 0,200 & 0,05 \\
\hline 6 & $\mathrm{~A}_{1} \mathrm{~B}_{2}$ & 14 & 0,200 & 0,05 \\
\hline 7 & $\mathrm{~A}_{2} \mathrm{~B}_{1}$ & 10 & 0,200 & 0,05 \\
\hline 8 & $\mathrm{~A}_{2} \mathrm{~B}_{2}$ & 12 & 0,200 & 0,05 \\
\hline
\end{tabular}

From the data in Table 3 , it can be seen that since the values of the significant level was higher than $\alpha_{0,05}$, it can be concluded that all the data of posttest scores are normal. Moreover, the results of homogeneity test are displayed in the following Table 4.

Based on the results of homogeneity testing, it shows that the values of $\chi^{2}{ }_{\text {obs }}<\chi^{2}$ table; thus, it can be concluded that the writing scores for each category were homogeneous. After having normality and homogeneity analysis, then we analyzed the data by using Two Way ANOVA inferential statistics. The results of Two Way ANOVA are listed in Table 5

Table 4. The summary of homogeneity test of posttest scores

\begin{tabular}{|c|c|c|c|c|c|c|}
\hline No & Variances & $\chi^{2}{ }_{\text {obs }}$ & $\chi_{\text {table }}^{2}$ & Test Result & Test Decision \\
\hline 1 & $\begin{array}{c}\text { Feedback } \\
\text { (Low Anxiety) }\end{array}$ & 0,696 & 3,84 & $\chi_{\text {obs }}^{2}<\chi_{\text {table }}^{2}$ & $\mathrm{H}_{0}$ is accepted \\
\hline 2 & $\begin{array}{c}\text { Feedback } \\
\text { (High Anxiety) }\end{array}$ & 0,897 & 3,84 & $\chi_{\text {obs }}^{2}<\chi_{\text {table }}^{2}$ & $\mathrm{H}_{0}$ is accepted \\
\hline 3 & Among samples & 1,499 & 7,815 & $\chi_{\text {obs }}^{2}<\chi_{\text {table }}^{2}$ & $\mathrm{H}_{0}$ is accepted & Homogeneous \\
\hline 4 & Writing Feedback & 1,24 & 3,84 & $\chi_{\text {obs }}^{2}<\chi_{\text {table }}^{2}$ & $\mathrm{H}_{0}$ is accepted & Homogeneous \\
\hline 5 & Anxiety & 3,60 & 3,84 & $\chi_{\text {obs }}^{2}<\chi_{\text {table }}^{2}$ & $\mathrm{H}_{0}$ is accepted \\
\hline
\end{tabular}

Table 5. The summary of $2 \times 2$ multifactor analysis of variance

\begin{tabular}{|c|c|c|c|c|c|}
\hline \multicolumn{6}{|c|}{ Tests of Between-Subjects Effects } \\
\hline \multicolumn{6}{|c|}{ Dependent Variable: posttest } \\
\hline Source & Type III Sum of Squares & $\mathrm{df}$ & Mean Square & $\mathrm{F}$ & Sig. \\
\hline Corrected Model & $1833,908^{\mathrm{a}}$ & 3 & 611,303 & 17,007 &, 000 \\
\hline Intercept & 194065,927 & 1 & 194065,927 & 5399,156 &, 000 \\
\hline feedback & 643,369 & 1 & 643,369 & 17,899 & ,000 \\
\hline anxiety & 999,451 & 1 & 999,451 & 27,806 &, 000 \\
\hline feedback $*$ anxiety & 318,715 & 1 & 318,715 & 8,867 & ,005 \\
\hline Error & 1545,581 & 43 & 35,944 & & \\
\hline Total & 196339,750 & 47 & & & \\
\hline Corrected Total & 3379,489 & 46 & & & \\
\hline
\end{tabular}

a. R Squared $=, 543$ (Adjusted R Squared $=, 511)$ 
Firstly, from the results of Two way ANOVA listed in Table 5 , it can be inferred that the value of $\mathrm{F}_{0}$ of interaction between writing feedback techniques and students' writing anxiety $(8,867)$ was higher than the value of $F_{\text {table }}(0,05)$ 4,00 . It means that there is an interaction between writing feedback techniques and students' writing anxiety toward students' writing achievement. In other words, the effect of writing feedback techniques on students' writing achievement depended on the degree of students' writing anxiety.

Secondly, the data analysis in Table 6 shows that the value of $\mathrm{F}_{0}$ among writing feedback techniques $(17,899)$ was higher than the value of $\mathrm{F}_{\text {table }}(0,05)(4,00)$; it means that there was a significant difference among group of students who were taught by using teacher intervention peer feedback and no teachers' intervention peer feedback writing techniques.

Thirdly, the results of the analysis show that the value of $\mathrm{F}_{0}$ among students' writing anxiety scores $(27,806)$ was higher than the value of $\mathrm{F}_{\text {table }}(0,05)(4,00)$. It means that there was a significant difference of writing ability between groups of students having low, medium and high writing anxiety.

Finally, based on the results of the calculation with Tukey-Kramer formula for students having low writing anxiety, it was found that $\mathrm{q}_{\text {obtained }}$ was 6,72 which was higher than $\mathrm{q}_{\mathrm{table}(0,05)}=2,83$. In other words, the writing achievement of group of students having low writing anxiety who were taught by using teachers' intervention peer feedback writing technique was better than that of those who were taught by using no teachers' intervention peer feedback writing technique. Meanwhile, for students having high writing anxiety, it was found that $\mathrm{q}_{\text {obtained }}$ was 1,65 which was lower than $\mathrm{q}_{\text {table }(0,05)}=2,83$. In other words, the writing ability of students having high writing anxiety after they were taught by using teachers' intervention peer feedback was similar to those who after they were taught by using no teachers' intervention peer feedback writing technique.

\subsection{Exploring Students' Perceptions of the Learning Activities}

Based on the results of descriptive analysis, it was found that, the students having low writing anxiety had perceived the learning activities with the implementation of teachers' intervention peer feedback very positively, it was reflected from the general mean score, 4, 22 indicating that they had strongly agreed towards the implementation of the technique. Meanwhile, those having high writing anxiety had also perceived the learning activities with the implementation of no-teachers' intervention peer feedback positively, it was reflected from the general mean score, 3,9 indicating that the students having high writing anxiety had agreed on the implementation of the technique.

Then, after doing the analysis by using Mann \& Whitney nonparametric test by using SPSS 20, we found that sig (2 tailed) was 0,0085 which was lower than $\alpha_{(0,05)}$. In other words, there was a significant difference between the perceptions of students having low and high writing anxiety toward the implementation of non-intervention peer feedback writing technique.

\section{Discussion}

Our study results shed important light on the impacts of teachers' intervention and no teachers' intervention peer feedback writing techniques (PFWT) on English as a foreign language (EFL) student teachers' essay writing ability and their perceptions of learning activities. Our study revealed that first there was an interaction among the implementation of no teachers' intervention and teachers' intervention peer feedback writing technique and students' language writing anxiety to students' writing ability. In other words, the implementation of no teachers' and teachers' intervention peer feedback writing technique had an significant effect on students' writing ability, and the effect was influenced by the different level of students' writing anxiety. Thus, the effect of the implementation of each writing feedback technique was influenced by the students' differences in their level of writing anxiety. Whenever the implementation of each writing technique could create the conducive learning situation that encourages a low affective filter, it will automatically give positive impact to students' performance especially for students having high writing anxiety. It is in line with Krashen (1982) who asserts that the input the students gain in learning is really influenced by their attitude. If their attitudes are not optimal, they will not only tend to seek less input, but they will also have a high or strong affective filter, even the input will not reach the language acquisition device located in their brain.

Moreover, we found that students' with low writing anxiety performed better compared to high writing anxiety. The group of the students having low writing anxiety who were taught by using no teachers' intervention peer feedback writing technique showed their significant improvement in their essay writing performance. This writing achievement improvement was supported by those students' positive perceptions/ attitude toward the learning activities. Meanwhile, students having high writing anxiety did not show significant improvement on their essay writing ability even though those students also showed their positive attitude toward the activities. The results of this study is in line with the studies conducted by Cheng (2002) and Hassan (2001) that showed similar findings that students with low writing anxiety had better writing performance than those with high writing anxiety.

Furthermore, our study indicated that the group of students having low and high writing anxiety and taught by using teachers' intervention peer feedback writing 
technique showed their significant essay performance improvement and this was supported by their positive attitude toward the learning activities and even low writing anxiety students perceived the learning activities very highly. It is in line with Zhang $(1995$, p.325) who calls "a judicious use of a combination use of a combination of feedback sources from the teacher and students' peers so that the affective disadvantage of peer feedback relative to teacher feedback maybe addressed responsibly and effectively in the ESL writing." Additionally, this study has provided clear empirical evidence that the phenomena of the implementation of both no teachers' intervention and teachers' intervention peer feedback could be described based on several facts. Firstly, students with low writing anxiety tended to have a good writing ability. When they were treated by using no teachers' intervention or teachers' intervention peer feedback writing technique, they could follow all the processes well. When they got involved in giving and sharing feedback, it seemed that the students enjoyed the processes of learning, and the process of peer feedback activities motivated them to be more responsible. It was because they had to give comments on their peers' essay in group. This phenomena was related to some researchers, who believe that the use of peer feedback in L1 settings as well as in ESL/ EFL writing classrooms should be practiced for releasing anxiety in writing by having such a collaborative face-to-face discussion in group, which could create enjoyable learning process as well as student's autonomy in learning (Mendonça \& Johnson, 1994; Villamil \& Guerrero, 1996). Yang, Badger, and Yu (2006) added that peer feedback is beneficial in developing critical thinking, learner autonomy and social interaction among students.

Besides, by giving and sharing feedback, the students were fostered to learn more in order to make them share good and appropriate comments on their friends' essay. By reading their peers' essays, giving comments, and considering their peers' comments to revise their essay, it made the students construct the knowledge through social sharing and interactions. It actually supports Vygotsky's theory (1978) which emphasized that the importance of social interaction with peers in theoretical construct of the Zone of Proximal Development suggested that writing skills could emerge with the mediation and help of others (Vygotsky, 1978 as cited in Hyland \& Hyland, 2006).

Secondly, even though low writing anxiety students had a significant improvement in their writing performance after they were taught by using no teachers' intervention peer feedback writing technique, the improvement was not too significant compared to those who were taught by using teachers' intervention peer feedback writing technique. It was proved that the role of the teacher to intervene the activities was really crucial. The pre-training sessions, which were given priority to the implementation of peer feedback would prepare the students for giving beneficial feedback to their peers. In the pre-training sessions, the students were given the guidelines. Then, the students were guided under a peer response task, which supplied priority and intention of teachers. By the pre-training activities, student's competence in reading and response to other students' papers could be promoted, which could decrease the difficulty of peer communication and discussion. Besides, the intervention from teachers during the activities could be as reviews to make sure everything runs properly. These training activities could increase students' awareness in doing all peer feedback activities well.

The significance of pre training prior feedback session was also asserted by several researchers. First, Esmaeli, Abasi and Sori (2004) revealed that the students incorporated significantly more comments into subsequent revisions after peer review training. Therefore, from the research, it was proved that peer review training had a positive effect on the students' subsequent revisions. Then, Min (2006) who conducted the study showed that students incorporated a significantly higher number of reviewers' comments into revisions post peer review training. The number of peer-triggered revisions comprised $90 \%$ of the total revisions, and the number of revisions with enhanced quality was significantly higher than that before peer review training. Min concluded that with extensive training inside and outside of class, trained peer review feedback can positively impact EFL students' revision types and quality of texts directly.

Meanwhile, students who got no training at all seemed a bit confused on how to give proper feedback to their peers and sometimes their feedback was not really influential in their peers' essay. Some of the students felt reluctant to give feedback, and after accepting the comments from their peers in group, it seemed that they got confused on how to deal with those comments to revise their essay. There were some researches showed the inability of the students to provide concrete and useful feedback (Leki, 1990; Mendonca \& Johnson, 1994; Lockhart \& Ng, 1993 and Tsui \& Ng, 2000). Students, both native speakers of English and learners who study English as a foreign language tend to give rubber stamp advice when reviewing peers' essays. Some attributed this phenomenon to students' lack of knowledge of English and skills for peer review and called for teachers' intervention.

Finally, the process of giving and sharing feedback was not proved significantly for students' having high writing anxiety. In the implementation of no teachers' intervention peer feedback, actually the students showed their positive attitude, but since all of the students generally did not have such a good writing ability, then the comments given by their peers did not really influence their development of their essay. They did not really know what to do to give comments to their friends and what they should do after accepting their peers' comments. In the meantime, teachers' intervention in peer feedback activities brought a significant influence on high writing anxiety students, they were much confident in and aware of what to do in doing 
all steps in giving and sharing feedback to their peers. Because of the pre-training sessions, they got a clear picture on how to give and share comments properly with their friends. Besides, the review from their lecturers given in the middle of the activities, advised them to give and share feedback more confidently.

\section{Conclusions}

The findings indicated that no teachers' and teachers' intervention had a significant impact on student teachers' writing ability and the impact was influenced by the different level of students' writing anxiety. Also, no teachers' intervention PFWT had a significant impact on student teachers' essay ability but not for those having high writing anxiety. Additionally, teachers' intervention PFWT had a significant effect on both students having low and high writing anxiety. Student teachers had a positive attitude toward the use of no teachers' intervention PFWT while students having low writing anxiety perceived teachers' intervention PFWT more positively compared to those having high writing anxiety.

The main problems of the implementation of collaborative peer feedback activities were majorly caused by students' lack of writing ability. The fact found in the group samples prior to the implementation of collaborative peer feedback writing activities was that most of the students still had poor writing skills. Teachers' intervention is such an alternative way to alleviate the problems faced in the implementation of peer feedback, but still needs to manage the intervention in order not to make students rely much on their teacher. Teachers' intervention peer feedback writing technique is the alternative solution to the problems faced by the implementation of collaborative peer feedback writing technique. Teachers' intervention could be used especially for writing courses in English as a foreign language context since the students generally have a low writing capability.

\section{REFERENCES}

[1] Alwasilah, A. C. (2006). From local to global: Reinventing local literature through English writing class. TEFLIN Journal, 17(1), 11-27.

[2] Ashwell, T. (2000). Patterns of teacher response to student writing in a multiple draft composition classroom: Is content feedback followed by form feedback the best method? Journal of Second Language Writing, 9(3), 227-257.

[3] Boas, I.V. (2011). Process writing and the internet: Blogs and Ning networks in the classroom. English Teaching Forum, 2, 26-33.

[4] Byrd, R.D. (2003). Practical tips for implementing peer editing tasks in the foreign language classroom. Foreign
Language Annals, 36 (3), 434-439.

[5] Byrne, D. (1993). Longman handbooks for language teachers: Teaching writing skills. Essex: Longman Group UK Limited.

[6] Cheng, Y.-S. (2002). Factors associated with foreign language writing anxiety. Foreign Language Annals, 35(5), 647-656.

[7] Cheng, Y.-S. (2004). A measure of second language writing anxiety: Scale development and preliminary validation. Journal of Second Language Writing, 13, 313-335.

[8] Cheng, Y. S, Horwitz, E. K., \& Schallert, D.L. (1999). Language writing anxiety: Differentiating writing and speaking components. Language Learning, 49, 417-446.

[9] Cohen, A. (1987). Student processing of feedback on their compositions. In A. Wendon and J. Rubin (Eds.), Learner strategies in language learning, New York, NY: Prentice Hall.

[10] Daly, J. A., \& Miller, M. D. (1975). The empirical development of an instrument to measure writing apprehension. Research in the Teaching of English, 9(3), 242-249.

[11] Dixon, R. (2005). Why put writing last? - Integrating the productive skills in general English classes. Paper presented in LIA International Conference 2005, Jakarta.

[12] Dörnyei, Z. (2003). Questionnaires in second language research: Construction, administration, and processing. Mahwah, NJ: Lawrence Erlbaum associates.

[13] Esmaeeli, H. Abasi, M and Soori, A. (2014). Is peer review training effective in Iranian EfL students' revision? Advances in Language and Literacy Studies, 5(4), 151-154.

[14] Failasofah, F., \& Dayij Alkhrisheh, H. T. (2018). Measuring Indonesian Students' Lexical Diversity and Lexical Sophistication. Indonesian Research Journal in Education $\mid$ IRJE|, 2(2), 97-107. https://doi.org/10.22437/irje.v2i2.6098

[15] Ferris, D. (2003). Responding to writing. In B. Kroll (Ed.), Exploring the dynamics of second language writing (pp. 119-140). Cambridge: Cambridge University Press.

[16] Ferris, D.R. (1995). Student reactions to teacher response in multiple-draft composition classrooms. TESOL Quarterly, 29(1), 35-53.

[17] Flower, L., \& Hayes, J. R. (1980). A cognitive process theory of writing. College Composition and Communication, 32(4), 365-387.

[18] Fraenkel \& Wallen. (2012). How to design and evaluate research in education. San Fransisco: McGraw Hill.

[19] Hassan, B. (2001). The relationship of writing apprehension and self-esteem to the writing quality and quantity of EFL University students. Mansoura Faculty of Education Journal, 39, 1-36.

[20] Holec, H. (1981). Autonomy in Foreign Language Learning. Oxford: Pergamon.

[21] Hyland, F. (2000). ESL writers and Feedback: Giving more autonomy to students. Language Teaching Research, 4(1), 
$33-54$.

[22] Hyland, K. (2002). Teaching and researching writing. Essex, England: Pearson Education.

[23] Hyland, K. (2003). Second language writing. Cambridge: Cambridge University Press.

[24] Hyland, K., \& Hyland, F. (2006). Feedback on second language students' writing. Cambridge: Cambridge University.

[25] Knoblauch, C.H., \& Brannon, L. (1984). Rhetorical traditions and the teaching of writing. Upper Montclair, N. J: Cook Publishers.

[26] Krashen, S.D. (1982). Principles and Practice in second language acquisition. Oxford: Pergamon Press

[27] Leki, I. (1990). Potential problems with peer responding in ESL writing classes. CATESOL Journal, 3, 5-19.

[28] Lockhart, C. \& Ng, P. (1993). How useful is peer response? Perspectives, 5(1), 17-29.

[29] Liu, J., \& Hansen, J. (2002) Peer response in second language writing classrooms. The University of Michigan Press: Michigan.

[30] Liu, M., \& Chai, Y.(2009). Attitudes towards peer review and reaction to peer feedback in Chinese EFL writing classrooms. TESL Reporter, 33-51.

[31] Makmur., Mukminin, A., Ismiyati, Y., \& Verawati. (2016). In search of good student teachers in writing skill: the impact of different task variance of EFL writing proficiency. International journal of academic research in education, 2(1).

[32] Mendoca, C., \& Johnson, K. (1994). Peer review negotiations: Revision activities in ESL writing instruction. TESOL Quarterly, 28(4), 745-768.

[33] Miao, Y., Badger, R., \& Zhen, Y. (2006). A comparative study of peer and teacher feedback in a Chinese EFL writing class. Journal of Second Language Writing, 15, 179-200.

[34] Min, H. (2006). The effects of trained peer review on EFL students' revision types and writing quality. Journal of Second Language Writing, 15(2006), 118-141.

[35] Mittan, R. (1989). The peer review process: Harnessing students' communicative power. In D.M. Johnson, \& D. H Roen (Eds.), Richness in Writing: Empowering ESL Students, New York, NY: Longman.

[36] Mukminin, A., Ali, R. M., \& Ashari, M. J. F. (2015). Voices from within: Student teachers' experiences in English academic writing socialization at one Indonesian teacher training program. The Qualitative Report, 20(9), 1394-1407.

[37] Nelson, G., \& Murphy, J. (1993). Peer response groups: Do L2 writers use peer comments in revising their drafts? TESOL Quarterly, 27(1), 135-142.

[38] Paulus, T.M. (1999). The effect of peer and teacher feedback on student writing. Journal of Second Language Writing, 8(3), 265-289.

[39] Pinako, S., \& Radzik, A. (1980). The student editing method.
Theory Into Practice, 19, 220-224.

[40] Reid, J. (1994). Responding to ESL students' texts: The myths of appropriation. TESOL Quarterly, 28(2), 273-294.

[41] Rollinson, P. (2005). Using peer feedback in ESL writing class. ELT Journal, 59(1), 23-30.

[42] Situmorang, K. (2018). Indonesian Students' Acquisition of English Address Terms: A Case Study in a University in the United Kingdom. Indonesian Research Journal in Education $\mid$ IRJE|, 2(2), 37-54. https://doi.org/10.22437/irje . $\mathrm{v} 2 \mathrm{i} 2.4970$

[43] Tsui, A.B.M., \& Ng, M.M.Y. (2000). Do secondary L2 writers benefit from peer comments? Journal of Second Language Writing. 9(2), pp. 147-170.

[44] Villamil, O.S., \& Guerrero, M.C.M. (1996). Peer revision in the L2 classroom: Social-cognitive activities, mediating strategies, and aspects of social behavior. Journal of Second Language Writing, 5(1), 51-75

[45] Yang, M., Badger, R., \& Yu, Z. (2006). A comparative study of peer and teacher feedback in Chinese EFL writing class. Journal of Second Language Learning, 15(3), 179-200. http://dx.doi. org/10.1016/j.jslw.2006. 09.004.

[46] Yarrow, F., \& Topping K. J. (2001). Collaborative learning: The effects of metacognitive prompting and structured peer interaction. British Journal of Educational Psychology, 71, 261-282.

[47] Zhang, S. Q. (1995). Reexamining the affective advantage of peer feedback in the ESL writing class. Journal of Second Language Writing, 4, 209-222.

[48] Zamel, V. (1985). Responding to student writing. TESOL Quarterly, 19, 79-101. 